\title{
TAF2 wt Allele
}

National Cancer Institute

\section{Source}

National Cancer Institute. TAF2 wt Allele. NCI Thesaurus. Code C52603.

Human TAF2 wild-type allele is located in the vicinity of $8 q 24.12$ and is approximately 102

$\mathrm{kb}$ in length. This allele, which encodes transcription initiation factor TFIID subunit 2

protein, plays a role in the regulation of initiation of RNA polymerase II-dependent transcription. 